DOI: https://doi.org/10.3126/tgb.v6i0.26165

\title{
Teaching Geography in Secondary School: Teachers Perceptions and Experiences
}

\author{
Keshav Raj Dhakal ${ }^{1}$
}

\begin{abstract}
Geography has the feature of being a science by examining the relationship of human and nature. Geography occupies very important role in school education. In secondary level education within Nepal there is a provision of selection of geography as an optional subject. This paper examines the perception and experiences about geography as an academic discipline from the teacher of secondary levels. Qualitative research method is used in this study and the semi structured interview method is applied. A semi structured interview guideline is applied for the participant in this study. Data are categorized into seven different groups and the analysis is carried out through the interpretations. The Research findings are discussed in relation to the theme and some recommendations have been given. This article provides useful information on the topic of perceptions and experiences of geography teachers on geography teaching in secondary school of Nepal.
\end{abstract}

Key words: perception, teaching geography, curriculum, textbook, effective teaching

\section{Introduction}

Geography is a discipline that seeks to understand the world in its physical and human features through an understanding of place and location. Geography combines both physical and human geography and looks at the interactions between the human and environment. According to Adhikari (2003) geography attempts to bridge the widening gap between the changing physical and biological phenomena on the one hand, and the changing human phenomena on the other (p.4).

Geography should be understood as a science that enquiries how this knowledge can be more useful for people by exerted it from being it just to be memorized the knowledge of the names and sizes of the mountain, river and lake. At present, geography is commonly referred to as the study of the environment and human's changing relationship. Subedi and Joshi (1997) stated that like most other social

${ }^{1}$ PhD Scholar, Central Department of Geography, Tribhuvan University. Corresponding email: dhakalkeshav@hotmail.com 
science disciplines, it is dynamic and over the last few decades changes have taken place in both the nature and scope of the discipline (p. 90).

Sanil, Sezer and Pinar (2016) review that the integration of technology to teaching, during their education, prospective geography teachers should be encouraged to produce technology aided instructional materials that could be utilized in teaching geography in under graduate level. Babacan (2018) concludes that most participants think primarily about holding a teaching position in state schools or having an academic career, while some intend to work as public servant, police officer, GIS expert and in different job positions in the private sector also. Wilmot and Irwin (2015) present the teachers' perceptions of the geography curriculum. Artvinil (2017) focuses the views of geography teachers on innovative geography teaching that the geography teachers are open and willing to use current education technologies in their classes, but with some challenges.

Geographical knowledge is very important for teachers, educationists, planners and policy makers of the country owing to geographical diversity of the country. In such context, effective geography teaching and learning is necessary in Nepal. In the early days of formal education implemented in the Nepal, geography was included in the school curriculum. However, nowadays, the subject is not in a position of high profile in the secondary school education. Therefore, it is necessary to find out the problems of geography teaching in secondary schools.

The present study brings out the factual realities of the perceptions and experiences of geography teachers of secondary level. This study is significant because it gives attention to geography teachers perceptions, they have their teaching experiences. There is dearth of literature in Nepal about the perception and experiences of secondary level teacher in Nepal. This paper addresses the gap in the current literature by placing an emphasis on understanding the perceptions of secondary level teacher to effective geography teaching. The main objective of this study is to find out the perceptions and experiences of geography teachers towards geography teaching in terms of instructional strategies, strength and weakness of curriculum, teaching methods, textbook, teaching materials, class room management, problems of teaching geography and suggestion to improve geography teaching at secondary schools.

\section{Methodology}

Qualitative research methods have been used in this study. This research is a descriptive study to gather teacher's perception and experiences about teaching 
geography in secondary levels. The research population of this study consisted of the teachers teaching geography at secondary school. Eight schools were selected for the study on the basis of purposive sampling out of sixteen community schools offering geography as an optional subject. Eight teachers who teach geography in sampled secondary schools were selected.

A semi structured interview guideline has been applied for the participant in this study. The researcher visited the sampled schools for collecting necessary data. Necessary data acquired through the interviews were determined. The primary mode of analysis is the development of categories or themes from the raw data. The themes were divided into seven groups as instructional strategies, strength and weakness of curriculum, teaching methods, textbook, teaching materials, class room management, problems of teaching geography and suggestion to improve geography teaching at secondary schools.

The secondary data were acquired from the review of the published and unpublished materials and electronic materials and documents of various organizations. Information regarding distribution of secondary schools, offering geography was acquired from official records. After collecting data, analysis of the data acquired was made through the interpretative method. The analysis was carried out through multiple readings and interpretations of the raw data.

\section{Result and discussion}

The survey was responded to by eight teachers teaching geography in eight different secondary schools located in Kathmandu district. Out of the total eight secondary level teachers teaching geography constituting the research population, all teachers are male. All teachers had at least bachelor's degree in geography from University. In terms of year of service, it is found that $50 \%$ of teacher had a teaching experience over 10 years, $25 \%$ had teaching experience between 5-10 years and $25 \%$ had a teaching experience less than 5 years. All teachers participated in training program after their appointment as a teacher.

\section{Instructional strategies}

Instructional strategies refer to methods used to help learn to students the desire course contents. Instructional strategy is the implementation of a long-term plan designed to achieve a goal followed in order to achieve learning. Instructional strategies comprise the principle and methods used by teachers to enable the students 
learning. Weston and Cranton (1986) viewed instructional strategies as both the teaching method and materials used in the process of teaching. Effective instructional

Table 1: Instructional strategies

\begin{tabular}{|l|c|}
\hline $\begin{array}{l}\text { Instructional } \\
\text { strategies }\end{array}$ & Frequency \\
\hline Interactive & 8 \\
\hline $\begin{array}{l}\text { Collaborative (group } \\
\text { work, team work and } \\
\text { discussion) }\end{array}$ & 8 \\
\hline Teacher centered & 8 \\
\hline Constructivist & 6 \\
\hline $\begin{array}{l}\text { Subject matter } \\
\text { centered }\end{array}$ & 5 \\
\hline Student centered & 3 \\
\hline
\end{tabular}

Source: Field survey, 2018. strategies can be used across grade levels and subject areas, available instructional materials and can accommodate a range of student differences.

According to findings all teachers have used interactive, collaborative and teacher centered strategies. An interactive classroom student talk than teacher talk. Students are given the opportunity to interact with teacher and with other students in interactive approach. Students will work as group work, team work and discussion in collaborative approach. The approaches called constructivist, subject matter centered and student centered are

also used by some teachers as instructional strategies in teaching in secondary schools.

\section{Teaching methods}

Geography should be taught as a very practical subject. It adds to one's knowledge, understanding and appreciation of the world around us. The variety of teaching and learning method which is used within geography is an important ingredient in creating a course with interest to students. A good teaching method helps the students to question their preconceptions, and motivates them to learn, by putting them in a situation in which they come to see themselves as the authors of answers, as the agents of responsibility for change.

According to the findings all teachers have used lecture, question answer, field work and discussion method in teaching geography at secondary schools. In lecture method teacher teaches orally to a group of students in class room. Question answer teaching method is a shared dialogue between teacher and student to achieve the cognitive objectives and bringing knowledge to conscious level. 
Table 2: Teaching methods

\begin{tabular}{|l|c|}
\hline Teaching Methods & Frequency \\
\hline Lecture & 8 \\
\hline Question answer & 8 \\
\hline Field work & 8 \\
\hline Problem solving & 7 \\
\hline Demonstration & 6 \\
\hline Discussion & 8 \\
\hline Laboratory method & 5 \\
\hline Narrative method & 6 \\
\hline $\begin{array}{l}\text { Project based } \\
\text { method }\end{array}$ & 4 \\
\hline
\end{tabular}

Source: Field survey, 2018.

Table 3: Strength of curriculum

\begin{tabular}{|l|c|}
\hline Strength of Curriculum & Frequency \\
\hline Knowledge of our country & 7 \\
\hline Knowledge about latitude and longitude & 3 \\
\hline Knowledge about climate and weather & 5 \\
\hline $\begin{array}{l}\text { Knowledge about natural resource and } \\
\text { maps }\end{array}$ & 7 \\
\hline Knowledge about agricultural pattern & 4 \\
\hline Encourage the use of technology & 7 \\
\hline Student centered curriculum & 6 \\
\hline Encourages research through observation & 5 \\
\hline Encourages learning by doing & 4 \\
\hline
\end{tabular}

Source: Field survey, 2018. schools.

Discussion is an active teaching method that encourages student to reflect their own experience. Fieldwork is regarded as an essential part of teaching and learning geography and all teachers agree that it represents one of the most effective and enjoyable forms of teaching and learning for both teachers and students. Though problem solving, narrative, demonstration and project based methods are used by some teachers as teaching method in teaching secondary

\section{Strengths and weakness of curriculum}

Curriculum is a tool in the hands of the teacher to mound his pupil according to his objective in the school. Curriculum is all the experiences of the pupil which is planned and directed by the school teachers to attain the objective of the education. Curriculum is an integration of need interest and skill of learners and helps to bring desire changes in learners. Curriculum also helps to prepare textbook, teaching manual and other reference materials.

According to findings geography curriculum has some strength like giving the knowledge of our country, knowledge about climate and weather, knowledge about natural resource and maps, knowledge about agricultural pattern etc. Encourage the use of technology, student centered curriculum, encourages research through observation, encourages learning 
by doing and knowledge about latitude and longitude are the other strength of geography curriculum.

According to the findings the geography curriculum has some weakness. It is seen

Table 4: Weakness of curriculum

\begin{tabular}{|l|c|}
\hline Weakness of curriculum & Frequency \\
\hline Poor performance in the S.E.E. exam & 7 \\
\hline Not job oriented subject & 6 \\
\hline $\begin{array}{l}\text { Gap on practical skills and } \\
\text { knowledge }\end{array}$ & 3 \\
\hline Heavily theoretical curriculum & 5 \\
\hline $\begin{array}{l}\text { Inadequacy of the infrastructure and } \\
\text { resources for implementation }\end{array}$ & 6 \\
\hline $\begin{array}{l}\text { Lacking vertical as well as horizontal } \\
\text { linkages }\end{array}$ & 3 \\
\hline
\end{tabular}

Source: Field survey, 2018. that the weaknesses relating to curriculum are poor performance in the S.E.E. exam. It is not job oriented subject at present, gap on practical skills and knowledge, heavily theoretical curriculum, inadequacy of the infrastructure and resources for implementation, lacking vertical as well as horizontal linkages etc.

\section{Teaching materials}

Teaching materials are resource to teacher which the teacher can use to help students learn a through visual and audio perception. Quality teaching materials help greatly to reinforce the students' initial desire to learn and to sustain enthusiasm throughout the course. Teaching materials plays a role in making knowledge accessible to a learner and can encourage the student to engage with knowledge in different ways and increase student's success. Okobia (2011) summarized the importance of using instructional materials in the classroom to include:
a. making the subject matter more real.
b. explicating difficult concepts.
c. making the learner experience what is being learnt.
d. helping to fire the imagination of the learners.
e. preventing misconceptions.
f. making learning interesting amongst others. 
Table 5: Teaching materials

\begin{tabular}{|l|c|}
\hline Teaching materials & Frequency \\
\hline $\begin{array}{l}\text { Printed materials (text book, reference } \\
\text { book, magazine, journal, newspaper, } \\
\text { teacher's manual) }\end{array}$ & 8 \\
\hline $\begin{array}{l}\text { Graphic materials (chart, graph, map, } \\
\text { atlas, globe, poster and diagram) }\end{array}$ & 8 \\
\hline $\begin{array}{l}\text { Audio visual materials (tape, cassette, } \\
\text { radio, photo, slide, overhead } \\
\text { projector, television, computer and } \\
\text { video) }\end{array}$ & 5 \\
\hline $\begin{array}{l}\text { Local materials (mud floor, stones, } \\
\text { bricks, stick, culture and tradition etc.) }\end{array}$ & 0 \\
\hline
\end{tabular}

Source: Field survey, 2018.
According to the findings all teachers have used printed materials (text book, reference book, magazine, journal, newspaper, teachers guide) frequently in teaching geography in secondary schools. All teachers used graphic materials (chart, graph, map, atlas, globe, poster and diagram) sometimes in teaching geography class room. Use of audio-visual materials (tape, cassette, radio, photo, slide, overhead projector, television, computer and video) in class room is occasional. Local materials (mud

floor, stones, bricks, stick, culture and tradition etc.) are not utilized as teaching materials.

\section{Geography text book}

Textbook is a book containing facts about a particular subject that is used by people studying that subject and are produced according to the demand of educational institutions. Widdowson and Lambert (2005) stated that textbooks have a key place in teaching learning. Textbook plays an important role in teaching and learning. It represents useful resource for teachers and learners. Textbooks are undoubtedly the most popular teaching materials use in classroom.

According to the geography teacher there are some defects of secondary level geography textbooks. The subject matters of the geography are not presented in the textbook according to the curriculum. All teacher said that the portion of mathematical geography is not appropriate in textbook. This portion has no practical utility in daily life. There are some errors in the geography textbook such as the problems on calculation of latitude and longitude. Most of the teacher said that geography of continents was too lengthy in the text book. Some statistical data are not updated in human and economic aspect in the text book. Some examples and figures are not appropriate in the text book. Examples based on local geography should be emphasized in text book. 


\section{Classroom management}

Classroom management comprises broad knowledge and skills of teacher (Steins, Wittrock and Haep, 2015). Classroom management is the wide variety of skills and techniques that teachers use to keep students organized, orderly focused, attentive and ensure that their classrooms runs smoothly without disruptive behavior of the student during class room.

Table 6: Class room management

\begin{tabular}{|l|c|}
\hline $\begin{array}{l}\text { Class room } \\
\text { Management }\end{array}$ & Frequency \\
\hline Eye contact & 8 \\
\hline $\begin{array}{l}\text { Gathering attention by } \\
\text { doing question-and- } \\
\text { answer }\end{array}$ & 8 \\
\hline Active teacher role & 6 \\
\hline $\begin{array}{l}\text { By providing active } \\
\text { participation in the } \\
\text { course }\end{array}$ & 5 \\
\hline $\begin{array}{l}\text { Good dialogue and } \\
\text { positive communication }\end{array}$ & \\
\hline
\end{tabular}

Source: Field survey, 2018.
According to the result obtained there are no teachers who have problem in classroom management. All of the teacher manages their class from eye contact and gathering attention by doing question answer method. Besides these method geography teachers also manage their classroom by applying other method. These methods are active participation of teacher and student in the classroom and course and good dialogue and positive communication between teacher and student in the class room. This type of class room management shows that their better efficiency in teaching in class room.

\section{Problems of geography teaching}

There are some problems of geography teaching at secondary school. A separate geography class room and laboratory are not available even a separate geography class room and laboratory for effective teaching are essential at the secondary schools. Reference materials on geography are not easily available at the market. Teaching mathematical concepts of geography is very difficult because mathematical geography is not included in higher education in geography. There is not sufficient availability of teaching materials to teach geography at the secondary level. And also, there is no provision of teacher training program by concerned authorities and no provision of workshop and seminars by educational institutions.

\section{Suggestions to improve geography teaching}

Secondary school's geography teachers gave some suggestions to improve geography teaching at secondary level. According to the teacher there should be separate 
geography class room and laboratory in each school. The concerning authorities should give teacher refresher programme. There should be provision of training programme to update the knowledge of geography teachers. There should be workshop and seminars for the geography teachers from educational institutions. Reference books and materials should be available in schools and geography curriculum should be job oriented. The respondents reported that there was a need of changing curriculum according to the need of the society and market demand. There was also a need of bringing changes in teaching learning methods/strategies using new technology like audio-visual devices. The respondents reported that the syllabus should also be changed in order to meet new challenges.

Public awareness program about geography education was to be launched. There was a need of increasing weightage for GIS, RS and practical courses.

\section{Conclusion}

The major task of teacher is to use classroom instructions and presentations to help students learning. School teachers play an important role in the overall development of students. Teaching is a profession in which the teacher becomes a model to the students and shows cognitive and affective behaviors and also the reflections of these behaviors through her/his own behaviors, attitudes and relations. According to finding interactive, collaborative and teacher centered strategies and methods are applied in the geography class room. There are some strength and weaknesses of geography curriculum and geography textbook. The finding of the research indicates that there are so many problems in teaching geography in secondary schools such as instructional materials, reference books, curriculum, textbooks etc. Teachers have positive perception and experience towards geography teaching in spite of various problems.

\section{References}

Adhikari, J. (2003). Geographical education and studies in Nepal. (Unpublished Seminar Paper). Kathmandu. Pp.1-35.

Artivinil. E. (2017). What is innovative geography teaching? A Perspective from geography teachers, Journal of Education and Training Studies, 5(6), 9-23.

Babacan, S. (2018). Pre-service geography teachers' perception of university education and their expectations of their field of study, International Journal of Geography and Geography Education, 38,119-126. 
Okobia, E.O. (2011). Availability and teachers' use of instructional materials and resources in the implementation of social studies in junior secondary schools in edo state. Review of European Studies, 3(3) December 2011. Retrieved from www.cesent. Org/res on 05/12/18.

Sanil,C., Sezer, A., \& Pinar, A. (2016). Perception of geography teachers to integrating technology to teaching and their practices, RIGEO, 6(3), 234-252. Retrieved from www.rigeo.org 6(3) winter/RIGEOV6 N3.pdf.

Steins, G. Wittrock, K. \& Haep, A. (2015) Contents of classroom management: What is necessary, what is possible? How is it done at school? Creative Education, 6, 2045-2062. Doi:10.4236/ce.2015.619210.

Subedi, B. P. \& Joshi. B. D. (1997). About geography in Nepal: An outline for discussion. In Prem K. Katry (edited), Social sciences in Nepal: Some thoughts and search for direction. Kathmandu: Center for Nepal and Asian Studies. Pp 90-112.

Weston C, \& Cranton P. (1986). Selecting instructional strategies. Journal of Higher Education. 5(3):260-254.

Widdoson, J. \& Lambert, D. (2015). Using geography textbooks. GA new secondary teacher's handbook. pdf file retrieved on Dec.1, 2018.

Wilmot, D. \& Irwin, P. (2015). South African teachers' perceptions of the primary geography curriculum: An exploratory study, RIGEO, 5 (2), 137-150. Retrieved from www.rigeo.org/vol5no2/Number2summer/RIGEOV5-N2-2.pdf 